This Journal is available in Telkom University online Journals

Jurnal Manajemen Indonesia

\title{
Online Shop Consumer Purchasing Decision: A Study on The Significance of Self-Esteem and Marketing Mix
}

Tety Elida ${ }^{1}$, Wahyu Rahardjo ${ }^{2}$, and Ari Raharjo ${ }^{3}$

${ }^{1,3}$ Faculty of Economics, Gunadarma University, Depok, West Java, Indonesia

${ }^{2}$ Faculty of Psychology, Gunadarma University, Depok, West Java, Indonesia

\begin{abstract}
The phenomenon of online shopping through various internet media broadens the scopes of studies in economics and psychology. The considerable factors which influence the purchasing decision of consumers in online shopping are the internal factors (e.g., self-esteem) and external factors (e.g., marketing mix). The aim of this study is to prove the constellation of self-esteem and marketing mix that can explain the purchasing decision of consumers in online shopping. The participants of this study are 270 online shoppers from various professions and ages. SEM is used to accomplish the objectives of the study. The findings showed that the empirical model achieved the goodness of fit which indicated that self-esteem and marketing mix had correlation with an online shopper purchasing decision. Moreover, the study found that self-esteem partially had no direct influence towards purchasing decision, yet it had a direct influence on marketing mix. On the other hand, marketing mix had a direct influence on purchasing decision.
\end{abstract}

Keywords — consumer behavior; self-esteem; marketing mix; purchasing decision; online shopping

\begin{abstract}
Abstrak
Fenomena perilaku membeli secara daring melalui berbagai media toko daring memberikan akses yang luas bagi disipilin ilmu ekonomi dan juga psikologi untuk menelaahnya. Beberapa hal yang ditengarai memengaruhi keputusan membeli konsumen toko daring adalah faktor internal seperti harga diri dan faktor eksternal seperti marketing mix. Tujuan dari penelitian ini adalah melihat apakah konstelasi harga diri dan marketing mix dapat menjelaskan keputusan membeli konsumen toko daring. Partisipan penelitian ini berjumlah 270 orang dari beragam profesi dan rentang usia yang menjadi konsumen toko daring. SEM digunakan dalam penelitian ini untuk menjawab pertanyaan penelitian. Hasil penelitian memperlihatkan bahwa model empirik yang diperoleh memiliki goodness of fit yang baik yang berarti bahwa harga diri dan marketing mix dapat menjelaskan keputusan membeli konsumen toko daring. Namun secara parsial diketahui bahwa harga diri tidak memiliki pengaruh langsung terhadap keputusan membeli, walaupun di sisi lain memiliki pengaruh langsung terhadap marketing mix. Sementara itu marketing mix memiliki pengaruh langsung terhadap keputusan membeli.
\end{abstract}

Kata kunci- bauran pemasaran; harga diri; keputusan beli; pembelian daring; perilaku konsumen;

\section{INTRODUCTION}

Borsenberger (2014) regarded e-commerce as a breakthrough of market limit due to geographical hindrances. Indonesia as a country with geographical state which consists of thousands of islands, reportedly created the highest online commerce between Southeast Asian countries, which reached \$27 million in 2018 (e-Economy SEA and Temasek, 2018). The contributions of online commerce do not come from people who live in big cities only, but also people who live in small cities in Indonesia (Mahatma, 2016). The rapid growth of online buying 
behavior nowadays is more likely because of the presence of a young troop as a millennial group which is familiar and keeping up with the technology growth (Lim et al., 2016).

At first, purchasing decision considered as a simple concept of how consumers perceive product price and consider if that is worth affording (Kottler and Keller, 2012). However, purchasing decision provided broader research-worth issues, it is not merely limited to product price perception. Mishra and Olshavsky (2005) stated that an individual had a limit of how much knowledge he or she knew, including product price knowledge. As a consequence, it emerged a tendency of prioritizing desire of satisfaction fulfilment than rationality gained from product knowledge. Thus, purchasing decision is often urged by heuristic aspects.

The previous studies on consumer purchasing decision were often conducted using Kottler's by involving classical variables thoroughly which were considered influential upon purchasing decision such as product information (Wang and Chang, 2013), price (Huang and Sarigollu, 2012; Hiransomboon, 2012; Scarpi, Pizzi, and Visentin, 2014; Bauboniene and Guleviciute, 2015), and promotion and place (Listyawati, 2017; Sundalangi, Mandey, Jorie, 2014).

The different external variables which have been studied and considered influential upon purchasing decision were the product insurance mechanism (Mousavizadeh, Kim, and Chen, 2016), and the contextual factors such as family, friendship, community, social status, and even religion (Leal, Hor-Meyll, and Pessoa, 2014; Papafotikas, Chatzoudes, and Kamenidou, 2014). Personal variables were rarely involved as the antecedent of purchasing decision. Thus, only a few was used, such as consumer characteristic factors (Azzadina, Huda, and Sianipar, 2012), cognitive aspects such as intuitive and rational ways of thinking (Kaufmann, Wagner, and Carter, 2017), and consumer product understanding (Karimi, Papamichail, and Holland, 2015).

The marketing mix serves as an effective marketing that approaches to attract consumers by several product key points, such as brand and price (Huang and Sarigollu, 2012). In fundamental, product marketing assists consumers to increase understanding regarding certain products. Thus, when the desire to satisfy needs and product knowledge meet, then the urge of purchasing grows stronger (Mishra \& Olshavsky, 2005). The understanding on brands as the results of good promotion strategies really helps consumers to consider and select products needed.

The online purchasing behaviours through web pages or certain social media required social knowledge before those get involved further in the purchasing process (Chen, Lu, and Wang, 2017). This social knowledge was gained by an individual through a social environment such as friends, fellow purchasers' reviews, internet mailing list forums, etc (Hajli, 2015). The accuracy and completeness of information regarding the products are often represented in the promotion published by producers and online shops as product retailers. At this point, the marketing mix contributes significant roles. Hiransomboon (2012) adds that price promotion that becomes critical as it is considered most prioritized by consumers before purchasing a product. In connection with this exposure, marketing mix in online business is closely related to information about products, pricing and promotional strategies. This study concerned with online shops then the place aspect was omitted.

One of the classical studies of Maile and Kizilbash (1977) also stated that effective product marketing should consider consumer self-esteem. Negative self-esteem caused careless consumers in considering product promotion and they do not perceive it further. Even products revealing contradictory information would not matter much for consumers with negative self-esteem. One of the aspects is assumed to influence purchasing decision is self-esteem as an internal or personal factor. Self-esteem is the degree of personal beliefs which positively consider oneself as a worthy person (Baron and Branscombe, 2012). Self-esteem is human basic needs. Life needs are numerous and the way a person achieves them probably depends on self-esteem he or she holds (Guindon, 2010).

Azzadina, Huda, and Sianipar (2012) stated that the profile of personal characteristics of consumers was related to how they perceive the promotion strategy of a product. Furthermore, self-esteem was also served as the important motivation of purchasing behaviors (Banister and Hogg, 2004). Truong and McColl (2011) added that self-esteem was a variable with an important role to understand consumer behaviors, especially related to specific or unique products. It meant that a certain degree of self-esteem of an individual could urge him or her to purchase or ignore a product with certain reasons. Truong and McColl (2011) also explained that negative self-esteem condition could push an individual to rush in purchasing a product he or she wants.

Self-esteem can have a negative influence on purchasing decision of a product. The more negative the selfesteem of an individual, the more anxious he or she gets in making a purchasing decision (Yurchisin and Johnson, 
2004). Similar findings published by Argo and White (2012) also stated that an individual with negative selfesteem had a tendency to be easily swayed to purchase a product due to its visual design.

In a different perspective, an interesting finding was stated by Zhang (2009) stating that self-esteem was often closely related to money. An individual with negative self-esteem had a stronger urgency to gain a lot of money (Juneman, Meinarno, and Rahardjo, 2012), or afforded expensive brands. In the context of consumptive behaviours, obtaining certain products is identical to how much money that he or she had. It could also relate to financial ownership of an individual. In other words, the amount of money possessed which became the source of prestige and personal self-esteem could also manifest in form of purchasing behaviours and in the purchased products. Hanley and Wilhelm (1992) stated that individuals with negative self-esteem tended to consider money expenditure as something that elevates prestige. It could also infer that individual with positive self-esteem but having a lot of money would also tend to easily purchase a product regardless of online or non-online products.

These elaborations emphasized that the existed a gap in the previous studies regarding purchasing decision. This study aimed at filling up one of the empty gaps which involved self-esteem as one of personal factors that influenced consumer's purchasing decision in online shopping.

\section{RESEARCH METHODOLOGY}

These elaborations emphasized that there is existed gap in the previous studies regarding purchasing decision. This study aimed at filling up one of the empty gaps which involved self-esteem as one of personal factors that influences consumer's purchasing decision in online shopping.

The participants of this study were 270 respondents consisted of mostly female $(\mathrm{N}=192 ; 71.48 \%)$, and male $(\mathrm{N}=78 ; 28.88 \%)$. The participant age ranged from 15 to 55 years old $(\mathrm{M}=22.47 ; \mathrm{SD}=5.69)$. The majority of participants' professions were university students $(\mathrm{N}=172 ; 63.70 \%)$, while the rest were employees of various professions $(\mathrm{N}=98 ; 36.29 \%)$.

The self-esteem was measured using the Rosenberg scale (1965). This scale was unidimensional with 10 items. One of the items' samples in this scale is "Overall, I am satisfied with myself". There were 2 items with an inadequate discriminant score while 8 items scored adequately. This scale had a reliability score of 0.796.

The marketing mix was measured using the adapted scale by Kotler and Keller (2016): product information, price, and promotion strategy. Each aspect had 5 items. One of the items' samples of the product aspect is "Information on the product I want to buy is valid". One of the items' samples of price aspect is "I shop online due to affordable prices generally offered". One of the items' samples of promotion strategy aspect is "Web provides a big discount in certain national holidays". Information product aspect scored 0.802 , price 0.808 while promotion strategy 0.722 in reliability.

The purchasing decision was measured using scale arranged based on the concept of purchasing decision by Kotler and Keller (2016): product selection, brand selection, dealer, and purchase timing. Since this study concerned about online shops then dealer option was ignored. Each aspect had five initial items. One of the items' samples of product selection is "I purchase products at the cheapest price". One of the items' samples of the brand selection is "I choose products with famous brands". One of the items' samples of purchase timing period is "I use a credit card for payment method". The product selection scored with reliability of 0.836 . Brand selection scored with reliability of 0.750 and purchase timing scored with reliability of 0.848 .

This study utilized the SEM approach or structural equation modelling for data analysis to provide empirical measurement to see if self-esteem and marketing mix could explain the purchasing decision of consumers in online shopping.

\section{RESULT AND DISCUSSION}

The study revealed a number of correlations among sub-variables. Purchasing decision due to product selection is correlated with all variables but self-esteem. Purchasing decision due to brand selection is correlated with all variables and sub-variables. Meanwhile, purchasing decision due to time selection is only correlated with promotion strategy. Self-esteem is not only correlated with the brand selection but also promotion strategy. Product marketing is correlated with purchasing decision due to product and brand. Marketing price is correlated 
with purchasing decision due to product and brand. Last, the promotion strategy is correlated with all purchasing decision due to product selection, brand, and purchasing time. These findings are shown in Table 1.

Table 1. Inter-variable Correlation

\begin{tabular}{|c|c|c|c|c|c|c|c|}
\hline & 1 & 2 & 3 & 4 & 5 & 6 & 7 \\
\hline 1 & & & & & & & \\
\hline 2 & $0.508^{* *}$ & & & & & & \\
\hline 3 & $0.381^{* *}$ & $0.392 * *$ & & & & & \\
\hline 4 & 0.043 & $0.134 *$ & 0.056 & & & & \\
\hline 5 & $0.264 * *$ & $0.279 * *$ & 0.106 & $0.157 * *$ & & & \\
\hline 6 & $0.146^{*}$ & $0.161 * *$ & -0.015 & 0.029 & $0.333^{* *} *$ & & \\
\hline 7 & $0.323^{* *}$ & $0.323 * *$ & $0.186^{* *}$ & 0.079 & $0.254^{* *}$ & $0.168 * *$ & \\
\hline $\mathrm{M}$ & 19.21 & 17.36 & 8.08 & 34.50 & 20.26 & 20.19 & 18.60 \\
\hline SD & 2.78 & 3.36 & 3.03 & 4.29 & 2.27 & 4.11 & 2.98 \\
\hline
\end{tabular}

Note: $1=$ product selection, $2=$ brand selection, $3=$ purchase timing, $4=$ self-esteem, $5=$ product, $6=$ price $7=$ promotion strategy $(*)=p<.05,(* *)=p<.01$

The findings also showed that the proposed theoretical model matched with the data collected. The generated empirical model scored Chi-Square of 12.346 with the probability of $0.338(\mathrm{p}<.05)$. This meant that the empirical model had the goodness of fit so that it could be said, self-esteem and marketing mix could explain consumer purchasing decision in an online shop. Promotion strategy became the only sub-variable or independent that could explain marketing mix. Meanwhile, the statistics indicated covariant or correlation between marketing mix in terms of product and price. It was reasonable as product promotion could not be separated from product price. In purchasing decision variables, purchasing decision due to brand selection was prominent followed by product variant selection and the time in which the products were purchased. It meant that brand selection still remained as first consideration of why a consumer finally decided to purchase a product online (Figure 1).

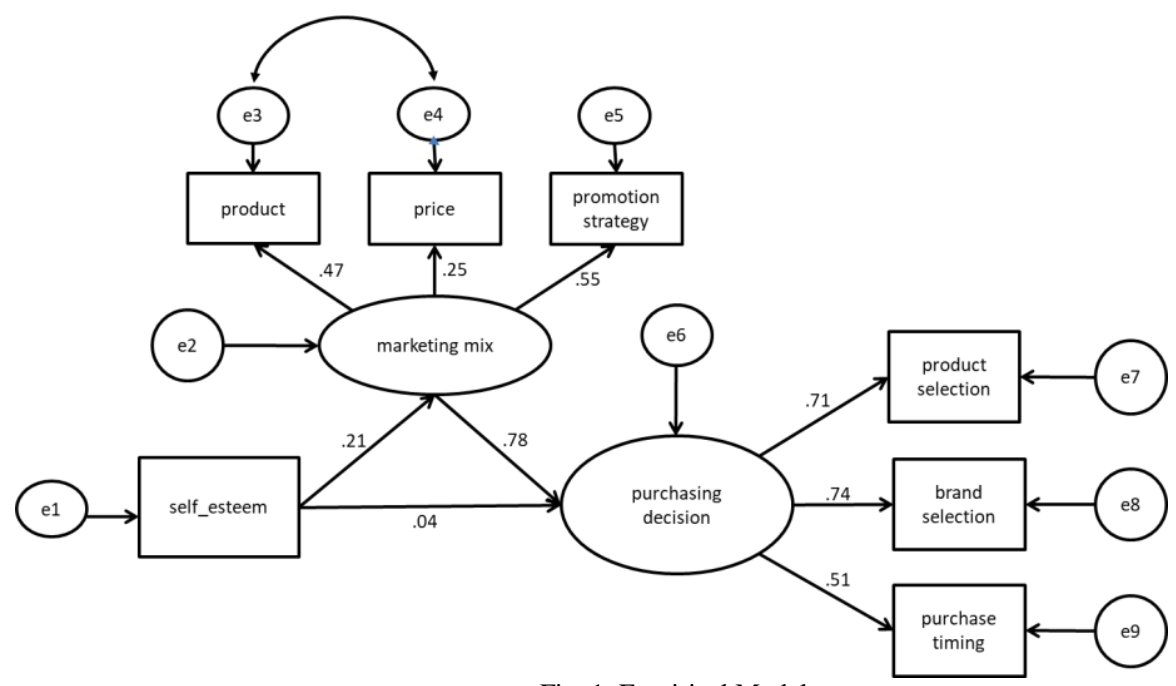

Fig. 1. Empirical Model

Partially, self-esteem had no direct significant influence on purchasing decision (Table 2 and Table 3). However, self-esteem had direct influence on marketing mix scoring at $0.210(p<.05)$, and marketing mix influenced purchasing decision about $0.776(p<.01)$.

Table 2. Regression weight

\begin{tabular}{|c|c|c|c|c|c|c|c|}
\hline & & & Estimate & S.E. & C.R. & $\mathrm{P}$ & Label \\
\hline marketing mix & $<---$ & self-esteem & .053 & .024 & 2.176 & .030 & \\
\hline
\end{tabular}




\begin{tabular}{|c|c|c|c|c|c|c|c|}
\hline & & & Estimate & S.E. & C.R. & $\mathrm{P}$ & Label \\
\hline puchasing_decision & $\begin{array}{l}<-- \\
\end{array}$ & self-esteem & -.018 & .039 & -.451 & .652 & \\
\hline puchasing_decision & $<--$ & marketing mix & 1.417 & .364 & 3.891 & $* * *$ & \\
\hline product selection & $<--$ & purchasing_decision & 1.000 & & & & \\
\hline brand selection & $<---$ & purchasing_decision & 1.269 & .163 & 7.778 & $* * *$ & \\
\hline purchase timing & $<---$ & purchasing_decision & .789 & .119 & 6.623 & $* * *$ & \\
\hline product & $<--$ & marketing mix & 1.000 & & & & \\
\hline price & $<---$ & marketing mix & .974 & .303 & 3.216 & .001 & \\
\hline promotion strategy & $<---$ & marketing mix & 1.533 & .335 & 4.569 & $* * *$ & \\
\hline
\end{tabular}

Table 3. The standardized regression weights

\begin{tabular}{llll}
\hline & & & Estimate \\
\hline marketing mix & $<---$ & self-esteem & .210 \\
purchasing_decision & $<---$ & self-esteem & -.039 \\
purchasing_decision & $<---$ & marketing mix & .776 \\
product selection & $<---$ & purchasing_decision & .706 \\
brand selection & $<---$ & purchasing_decision & .741 \\
purchase timing & $<---$ & purchasing_decision & .511 \\
product & $<---$ & marketing mix & .472 \\
price & $<---$ & marketing mix & .254 \\
promotion strategy & $<---$ & marketing mix & .553 \\
\hline
\end{tabular}

In terms of comparison based on gender, then several findings were revealed (Table 4). Male participant group considered product purchasing time more than female. They also perceived product promotion positively compared to female. On the other hand, the male participant group appeared to have higher self-esteem than female.

Table 4. The comparison of all variables based on gender

\begin{tabular}{cccccccc}
\hline & 1 & 2 & 3 & 4 & 5 & 6 & 7 \\
\hline Male $(\mathrm{N}=78)$ & 19.27 & 17.87 & 8.72 & 20.92 & 20.44 & 18.46 & 35.82 \\
Female $(\mathrm{N}=192)$ & 19.19 & 17.15 & 7.82 & 19.98 & 20.08 & 18.66 & 33.96 \\
t score & 0.218 & 1.613 & 2.215 & 3.119 & 0.637 & -0.486 & 3.291 \\
sig. &.$n s$ &.$n s$ & $p<.05$ & $p<.01$ &.$n s$ &.$n s \quad$ & $p<.01$
\end{tabular}

Note: 1 = product selection, 2 = brand selection, $3=$ purchase timing, $4=$ product, $5=$ price, $6=$ promotion strategy, $7=$ self-esteem

Davis, Smith, and Lang (2017) claimed females to be more anxious over online shopping security than males, as they required longer consideration time in deciding to purchase products. Interestingly, findings in this study disproved. Males, instead, showed a higher tendency to think and consider purchasing time than females. Explainable reason for this was that products purchased by the males in online shopping were mostly electronics and sports equipment which posted higher risk of disadvantage values compared to the products purchased by the females which were mostly fashion.

The more impulsive online shopping behaviours of females could occur because of fashion products purchased which did not emphasize utilities compared to the electronic and sports products purchased by the males. Hasan (2010) explained that females barely considered utilities in online shopping. In contrast, males prioritized utility aspects in online shopping. In short, the higher the perception of necessities on certain products, the stronger the male urge to purchase.

One of the foremost aspects of product marketing is brand. A brand can contribute stronger purchasing appeal than its price. Ye, Liu, and Shi (2015) stated that some individuals who had lower self-esteem prefer popular and 
expensive brands to increase self-esteem. Consequently, the tendency to perceive product promotion positively due to brand rises.

Product marketing can also utilize ads. Interesting and eye-catching product ads can touch self-esteems by visual and trigger individuals to purchase. These ads are viewable to individuals through various mass media and influence them when accessing online shop Webpages on the internet. Jun, Jeong, Gentry, and Hyun (2015) mentioned that ads product could seem to reflect certain characteristics of individuals so they felt represented. Durgee (1986) defined this as self-esteem advertising where product ads were intentionally made to awaken positive feeling in individuals who watch the ads. Next, individuals with lower self-esteem easily believe in product marketing promotions as they consider that the products represent themselves so much.

The finding revealed that self-esteem had no direct influence on purchasing decision is interesting to discuss. Kropp, Lavack, and Silvera (2005) agreed that self-esteem might not directly influence individuals' decision in product purchasing. Self-esteem likely influenced individual internal values beforehand in deciding to purchase certain products or not. These internal values help individuals in perceiving product image perceive based on their opinions. At last, individuals then decide to purchase the products or not. Narang (2016) found that personal selfesteem firstly influenced purchasing intent. This indicates that purchasing intention lies in between self-esteem and purchasing decision. Whether purchasing intention turns into purchasing decision or not is a different matter.

On the other hand, the fact that many university students become participants in this study enriched it with another understanding upon the significance of self-esteem on purchasing decision. One of the strongest selfesteem sources is the external factor-which is friends of similar age. University students are categorized as a group fond of friends' influences. Thus, self-esteem tends to develop as communal or collective. Self-esteem is shared within the group. As a result, the internal values and consumptive behaviours over certain products are also influenced by collective self-esteem rather than personal (Kropp, Lavack, and Silvera, 2005).

The number of female participants in this study contributed to the unavailability of the relation between selfesteem and purchasing decision. The finding of this study revealed that the most purchased products by participants were fashion rating to $65.92 \%$ out of other product categories. Khare, Mishra, and Parveen (2012) explained that female self-esteem in considering positive assessment of fashion product promotions was developed from the way she perceived how the environment perceived about herself. This kind of self-esteem belongs to public self-esteem as it is so much influenced by the external environment feedbacks (Khare, Mishra, and Parveen, 2012). The negative communal self-esteem turned individual's dependent on positive opinions from the closest persons to them (Hunt, 2010). This collective self-esteem is then strengthened with the valuable normative values in the environment, particularly on positive or negative environment assessment towards individual behaviours (Khare, Mishra, Parveen, and Srivastava, 2012). As a matter of fact, the more interesting a fashion product promotion be, the more it attracts individuals with lower self-esteem to purchase.

The study found another interesting finding to explain how self-esteem did not show significant influence on purchasing decision. Kressmann at al. (2006) defined self-congruity as a process of adjusting the personal image with the products purchased. In addition, he elaborated the significance of self-esteem on self-congruity. The farther the gap between personal image and product image, the bigger the self-congruity becomes. The issue was that products sold online could not be as sophisticated as those sold in the retail shops at malls or special outlets. This explained why participants did not encounter self-congruity as no collision occurred between self-esteem and online products. In other words, it is highly probable that the participants of this study did not purchase products to get positive self-esteem, but rather to fulfil real needs or merely to entertain. Verplanken and Sato (2011) stated that purchasing decision derives by needs to utilize product utilities are not influenced by consumer's self-esteem.

The significant influence of marketing mix on purchasing decision is considered rational. Effective marketing strategy suits special characteristics of the products could attract consumers to purchase. Lim at al. (2016) found that marketing strategy influences personal subjective norms. This positively affects individual reasoning and purchasing decision.

Another finding of this study showed that male consumers focused on purchasing products really needed, favoured, and considered urgent such as electronics etc. Product utilities commonly depended on price. Thus, when an individual concerned about utility functions and personal preferences, the price was next to consider purchasing online products (Scarpi, Pizzi, and Visentin, 2014). Whenever an individual considered the offered price affordable, then he or she would surely purchase the product. Several studies agreed on product promotion was offering most affordable price. It could contribute significant urge to individuals for purchasing the products (Astuti, Silalahi, and Wijaya, 2015; Kusumawati, Oswari, Utomo, and Kumar, 2014). 
Product contextuality in the market is also contributed important influence. Azzadina, Huda, and Sianipar (2012) found that the most marketing mix influenced by personal factors were firstly sale location, the price, and lastly the product itself. In an online context, the online shop webpage layout becomes crucially determining. Attractive view and easy navigation for browsing the products become part of the most important promotion strategy to be emphasized by marketers (Ong, 2011). In this study, the high influence of marketing mix on purchasing decision was likely influenced by that. As participants of this study were fond consumers of popular online shop websites, such as Tokopeda, Lazada, Bukalapak, Blibli, Zalora, Toko Bagus, Matahari Mall, Shopee, and even Instagram which are served as a social media oftenly used as online marketing media.

These online shops have various characteristics which can attract individuals to purchase products as they create attractive layouts, detail product information, and easy navigation for consumers to browse product variants available. Furthermore, these online shops have transformed into kinds of electronic brands (e-brand). Electronic brands popular to consumers, particularly loyal the ones, would trigger strong attachment or preference (Park, Lee, and Lee, 2005). As consequences, consumers put trust in those online shop brands and purchase products using them as they believe in those brands.

For the university students, which are categorized as millennial generation, certain brands remain as the most preferable. High emotional urge often determines young millennial generation to purchase products, especially online products (Bilgihan, 2016). Popular brands are now available abundantly in online shops attract this generation to shop online even more. Gonzalez-Benito, Martos-Partal, and Martin (2015) stated that brands played an important role in the online shop compared to a conventional shop. Consequently, the promotion for strengthening brand becomes more important. The fact that brand promotion is considered necessary to increase the value of the brand also to emphasize that the marketing mix is beneficial to be implemented to influence the purchasing decision of a young generation.

Another understanding that can be brought is online shop as a fundamental retail shop. It means that consumers are not always introduced to sophisticated brand selection, big sizes, limited edition and else. The purchased products by participants in this study are products of retail characteristics, such as fashion e.g., clothes, cosmetics, toys, household utensils, and sports equipment. The products which are categorized as expensive as in electronics, those were mostly purchased by male participants. The retail products in an online shop should offer more selling value than those sold in conventional shops. Most important comparison aspect is the price. Consumers might have chosen to purchase products in conventional shops if online shops did not offer any cheaper prices. This had been in line with findings of Wongleedee (2015) stated that price played an important role in retail products as differentiating aspect. Cheaper prices would invite consumers to visit and purchase. Brands surely played an important consideration for consumers in purchasing products, yet price served as differentiating factor in promotion strategy which was crucial for individuals in purchasing products (Abril and Rodriguez-Canovaz, 2016; Close and Kukar-Kinney, 2010).

\section{CONCLUSION}

This study summed up several findings. First, self-esteem as an internal factor had no direct influence on purchasing decision. It was highly probable to assume that mediatory variables between self-esteem and purchasing decision existed. Second, self-esteem influenced the perception of product promotion strategy, and promotion strategy had a strong influence on purchasing decision. Third, male considered purchasing time more than female, be more positive to perceive product promotion and had higher self-esteem.

This study had several weaknesses. First, personal factors need to be studied further, particularly other internal variables have crucial roles in influencing the purchasing decision. Several matters worth considering is computer self-efficacy, shopping motivation (Pappas at al. 2017), personal regulation (Fishbach and Zhang, 2009), and personal attitude towards online shopping (Liu and Forsythe, 2010; Ong, 2011; Yang and Lester, 2008) and attitudes of other people over the products that participants wanted to purchase (Kottler and Keller, 2016). Second, the participants' inclusive criteria of early adulthood category were not specific, thus it did not contribute significantly towards findings. Lissitsa and Kol (2016) explained that despite university students as young generation being a potential market target, yet adult group valued more as the potential market target as they had better purchase financial and freer time in online shopping. 


\section{REFERENCES}

Abril, C., \& Rodriguez-Canovaz, B. (2016). 'Marketing mix effects on private labels brand equity'. European Journal of Management and Business Economics, 25(3), 168-175. http://dxdoi.org/10.1016/j.redeen.2016.09.003

Argo, J.J., \& White, K. (2012). 'When do consumers eat more? The role of appearance self-esteem and food packaging cues'. Journal of Marketing, 76, 67-80. http://doi.org/10.1509/ jm.09.0512.

Astuti, R., Silalahi, R.L.R., \& Wijaya, G.D.P. (2015). 'Marketing strategy based on marketing mix influence on purchasing decisions of Malang apples consumers at Giant Olympic Garden Mall (MOG), Malang City, East Java Province, Indonesia'. Agriculture and Agricultural Science Procedia, 3, 67-71.

Azzadina, I., Huda, A.N., \& Sianipar, C.P.M. (2012). 'Understanding relationship between personality types, marketing mix factors, and purchasing decisions'. Procedia Behavioral and Social Sciences, 65, 352-357.

Banister, E.N., \& Hogg, M.K. (2004). Negative symbolic consumption and consumers' drive for self-esteem: The case of the fashion industry. European Journal of Marketing, 38(7), 850-865.

Baron, R.A., \& Branscombe, N.R. (2012). Social psychology (thirteenth edition). New Jersey: Pearson Education Inc.

Bilgihan, A. (2016). 'Gen Y customer loyalty in online shopping: An integrated model of trust, user experience and branding'. Computers in Human Behavior, 61, 103-113. http://dx.doi.org/10.1016/j.chb.2016.03.014

Borsenberger, C. (2014). 'The concentration phenomenonin e-commerce', in Crew, M.A. \& Brenna,n T.J. (Eds.), Postal and delivery innovation in the digital economy. London: Springer. pp. 31-41.

Chen, A., Lu, Y., \& Wang, B. (2017). 'Costumers' purchase decision-making process in social commerce: A social learning perspective'. International Journal of Information Management, 37, 627-638. http://dx.doi.org/10.1016/j.ijinfomgt.2017.05.001

Close, A.G., \& Kukar-Kinney, M. (2010). 'Beyond buying: Motivations behind consumers' online shopping cart use'. Journal of Business Research, 63, 986-992.

Davis, R., Smith, S.D., \& Lang, B. (2017). 'A comparison of online and offline gender and goal directed shopping online'. Journal of Retailing and Consumer Services, 38, 118-125. http://dx.doi.org/10.1016/j.jretconser.2017.02.011

Durgee, J.F. (1986). 'Self-esteem advertising'. Journal of Advertising, 15(4), 21-42.

Fishbach, A., \& Zhang, Y. (2009). 'The dynamics of self-regulation: When goals commit versus liberate', in Wanke, M. (Ed.), Social psychology of consumer behavior (New York: Psychology Press. pp. 365-386.

Gonzalez-Benito, O., Martos-Partal, M., \& Martin, S.S. (2015). 'Brands as substitutes for the need for touch in online shopping'. Journal of Retailing and Consumer Services, 27, 121-125. http://dx.doi.org/10.1016/j.jretconser.2015.07.015

Guindon, M.H. (2010). 'What is self-esteem?', in Guindon, M.H. (Eds.), Self-esteem across the life span New York: Routledge. pp. 3-24.

Hajli, N. (2015). 'Social commerce constructs and consumer's intention to buy'. International Journal of Information Management, 35, 183-191. http://dx.doi.org/10.1016/j.ijinfomgt. 2014.12.005

Hanley, A., \& Wilhelm, M.S. (1992). 'Compulsive buying: An exploration into self-esteem and money attitudes'. Journal of Economic Psychology, 13, 5-18. https://doi.org/10.1016/0167-4870(92)90049-D

Hasan, B. (2010). 'Exploring gender differences in online shopping attitudes'. Computers in Human Behavior, $26,597-601$.

Hiransomboon, K. (2012). 'Marketing mix affecting accommodation service buying decisions of backpacker tourist traveling at Inner Rattanakosin Island in Bangkok, Thailand'. Procedia Economics and Finance, 3 , 276-283.

Huang, R., \& Sarigollu, E. (2012). 'How brand awareness relates to market outcome, brand equity, and the marketing mix'. Journal of Business Research, 65, 92-99.

Hunt, B. (2010). 'Young women and self-esteem', in Guindon, M.H. (Eds.), Self-esteem across the life span New York: Routledge. pp. 3-24.

Jun, S., Jeong, Y., Gentry, J.W., \& Hyun, Y.J. (2015). 'The moderating effect of self-esteem on consumer responses to global positioning in advertising'. International Journal of Advertising, 36(2), $272-292$. http://dx.doi.org/10.1080/02650487.2015.1094859

Juneman, Meinarno, E.A., \& Rahardjo, W. (2012). 'Symbolic meaning of money, self-esteem, and identification with Pancasila values'. Procedia Social and Behavioral Sciences, 65, 106-115.

Karimi, S., Papamichail, K.N., \& Holland, C.P. (2015). 'The effect of prior knowledge and decision-making style on the online purchase decision-making process: A typology of consumer shopping behavior'. Decision Support Systems, 77, 137-147. http://dx.doi.org/10.1016/j.dss.2015.06.004 
Kaufmann, L., Wagner, C.M., \& Carter, C.R. (2017). 'Individual modes and patterns of rational and intuitive decision-making by purchasing managers'. Journal of Purchasing and Supply Management, 23(2), 82-93. https://doi.org/10.1016/j.pursup.2016.09.001

Khare, A., Mishra, A., \& Parveen, C. (2012). 'Influence of collective self-esteem on fashion clothing involvement among Indian women'. Journal of Fashion Marketing and Management: An International Journal, 16(1), 42-63. https://doi.org/10.110813612 021211203023

Khare, A., Mishra, A., Parveen, C., \& Srivastava, R. (2011).' Influence of consumers' susceptibility to interpersonal influence, collective self-esteem and age of fashion clothing involvement: A study on Indian consumers'. Journal of Targeting, Measurement and Analysis for Marketing, 19, 227-242.

Maile, C. A., \& Kizilbash, A. H. (1977). 'A marketing communications model'. Business Horizon, 20, (6), 7784.

Kottler, P., \& Keller, K.L. 2012. Marketing management. New Jersey: Pearson Education, Inc.

Kotler, P., \& Keller, K.L. (2016). A framework for marketing management (sixth edition). Essex: Pearson.

Kressmann, F., Sirgy, M.J., Herrmann, A., Huber, F., Huber, S., \& Lee, D.J. (2006). 'Direct and indirect effects of self-image congruence on brand loyalty'. Journal of Business Research, 59, 955-964.

Kropp, F., Lavack, A.M., \& Silvera, D.H. (2005). 'Values and collective self-esteem as predictors of consumer susceptibility to interpersonal influence among university students'. International Marketing Review, 22(1), 7-33.

Kusumawati, R.D., Oswari, T., Utomo, R.B., \& Kumar, V. (2014). 'The influence of 7P's of marketing mix on buying intention of music product in Indonesia'. Procedia Engineering, 97, 1765-1771.

Leal, G.P.A., Hor-Meyll, L.F., \& Pessoa, L.A.G.d.P. (2014). 'Influence of virtual communities in purchasing decisions: The participants' perspective'. Journal of Bussiness Research, 67, 882-890. http://dx.doi.org/10.1016/j.jbusres.2013.07.007

Lian, J.W., \& Lin, T.M. (2008). 'Effects on consumer characteristics on their acceptance of online shopping: Comparisons among different product types'. Computers in Human Behavior, 24, 48-65.

Lim, Y.J., Osman, A., Salahuddin, S.N., Romle, A.R., \& Abdullah, S. (2016). 'Factors influencing online shopping behavior: The mediating role of purchase intention'. Procedia Economics and Finance, 35, 401410 .

Lissitsa, S., \& Kol, I. (2016). 'Generation X vs. generation Y - A decade of online shopping'. Journal of Retailing and Consumer Services, 31, 304-312. http://dx.doi.org/10.1016/j. jretconser2016.04.015

Listyawati, I.H. (2017). 'Pengaruh Lokasi, Kelengkapan Produk, Kualitas Produk Dan Promosi Terhadap Keputusan Beli Konsumen Di Pamella Empat Yogyakarta'. Jurnal Bisnis, Manajemen, dan Akuntansi, IV, $2,50-59$.

Liu, C., \& Forsythe, S. (2010). 'Sustaining online shopping: Moderating role of online shopping motives'. Journal of Internet Commerce, 9(2), 83-103.

Mahatma, R. (2016). Data statistik mengenai pertumbuhan pangsa pasar e-commerce di Indonesia saat ini. https://buattokoonline.id/data-statistik-mengenai-pertumbuhan-pangsa-pasar-e-commerce-di-indonesiasaat-ini/ Diakses tanggal 28 Agustus 2017.

Maile, C.A., \& Kizilbash, A.H. (1977). 'A marketing communication model'. Business Horizons, 20(6), 77-84. https://doi.org/10.1016/0007-6813(77)90029-5

Mishra, S., \& Olshavsky, R.W. (2005). 'Rationality unbounded: The internet and its effect on consumer decision making', in Haugtvedt, C.P., Machleit, K.A \& Yalch, R.F(Eds.), Online consumer psychology: Understanding and influencing consumer behavior in the virtual world New Jersey: Lawrence Erlbaum. pp. 361-378.

Mousavizadeh, M., Kim, D.J., \& Chen, R. (2016). 'Effects of assurance mechanism and consumer concerns on online purchase decisions: An empirical study'. Decision Support Systems, 92, 79-90. http://dx.doi.org/10.1016/j.dss.2016.09.011

Narang, R. (2016). 'Understanding purchase intention towards Chinese products: Role of ethnocentrism, animosity, status and self-esteem'. Journal of Retailing and Consumer Services, 32, 253-261. https://doi.org/10.1016/j.jretconser.2016.05.010

Ong, B.S. (2011). 'Online shoppers' perceptions and use of comparison-shopping sites: An exploratory study'. Journal of Promotion Management, 17, 207-227.

Pappas, I.O., Kourouthanassis, P.E., Giannakos, M.N., \& Lekakos, G. (2017). 'The interplay of shopping motivations and experiental factors on personalized e-commerce: A complexity theory approach'. Telematics and Informatics, 34, 730-742. http://dx.doi.org/10.1016/ j.tele.2016.08.021 
Park, J.W., Lee, H.J., \& Lee, H.I. (2005). 'Consumer relationships with an e-brand: Implications for e-brand extensions', in Haugtvedt, C.P., Machleit, K.A. \& Yalch, R.F. (Eds.), Online consumer psychology: Understanding and influencing consumer behavior in the virtual world. New Jersey: Lawrence Erlbaum. pp. 379-399

Rosenberg, M. (1965). Society and the adolescent self-image. Princenton University Press, New Jersey.

Scarpi, D., Pizzi, G., \& Visentin, M. (2014). Shopping for fun or shopping to buy: Is it different online and offline?'. Journal of Retailing and Consumer Services, 21, 258-267. http://dx.doi.org/10.1016/j.jretconser.2014.02.007

Sundalangi, M., Mandey, S.L., Jorie, J. (2014). 'Kualitas Produk, Daya Tarik Iklan, Dan Potongan Harga Terhadap Minat Beli Konsumen Pada Pizza Hut Manado'. Jurnal EMBA: Jurnal Riset Ekonomi, Manajemen, Bisnis dan Akuntansi, 2,1, 313-324.

Truong, Y., \& McColl, R. (2011). 'Intrinsic motivation, self-esteem, and luxury goods consumption'. Journal of Retailing and Consumer Services, 18, 555-561.

Verplanken, B., \& Sato, A. (2011). 'The psychology of impulse buying: An integrative self-regulation approach'. Journal of Consumer Policy, 34, 197-210.

Wang,J.C.,\& Chang,C.H. (2013). 'How online social ties and product related risks influence purchase intentions: a Facebook experiment'. Electronic Commerce Research and Applications, 12, 5, 337-346.

Wongleedee, K. (2015). 'Marketing mix and purchasing behavior for community products at traditional markets'. Procedia Social and Behavioral Studies, 197, 2080-2085.

Yang, B., \& Lester, D. (2008). 'Sex differences in online shopping: An exploratory study'. Psychological Reports, $102,723-726$.

Ye, S.H., Liu, X.T., \& Shi, S.Y. (2015). 'The research of status' influence on consumers' self-brand connection with luxury brands: Moderating role of self-esteem and vanity'. Open Journal of Business and Management, 3, 11-19. http://dx.doi.org/10.4236/ojbm.2015.31002

Yurchisin, J., \& Johnson, K.K.P. (2004). 'Compulsive buying behavior and its relationship to perceived social status associated with buying, materialism, self-esteem, and apparel-product involvement'. Family and Consumer Sciences Research Journal, 32(3), 291-314.

Zhang, L. (2009). 'An exchange theory of money and self-esteem in decision making'. Review of General Psychology, 13(1), 66-76. 